\title{
PENERAPAN MODEL PEMBELAJARAN GENERATIF UNTUK MENINGKATKAN AKTIVITAS DAN HASIL BELAJAR SERVIS DALAM PERMAINAN BOLAVOLI
}

\author{
I Km. Sukarata Adnyana ${ }^{1}$, P. Gunarto ${ }^{2}$ \\ 1,2 Jurusan Penjaskesrek, Universitas Pendidikan Ganesha \\ Singaraja, Indonesia \\ e-mail: sukarata.adnyana@undiksha.ac.id, peby.gunarto@undiksha.ac.id
}

\begin{abstract}
Abstrak
Penelitian ini bertujuan untuk mengetahui bagaimanakah aktivitas dan hasil belajar bolavoli siswa melalui penerapan model pembelajaran generatif. Metode penelitian secara kuantitatif dan dilaksanakan 2 siklus, tiap siklus terdiri dari perencanaan, pelaksanaan, observasi dan refleksi. Subjeknya adalah siswa kelas VIII A2 SMP Negeri 4 Singaraja berjumlah 42 orang. Hasil analisis data siklus I yaitu, aktivitas belajar siswa secara klasikal $(\bar{A})$ sebesar 71,68\%, dikonversikan dalam kriteria aktivitas belajar siswa tergolong aktif, penguasaan materi secara klasikal $66,67 \%$ berada dalam rentang $(65 \%$ 74\%) kategori cukup baik. Hasil analisis data siklus II yaitu, aktivitas belajar siswa secara klasikal ( $\bar{A}$ ) sebesar 91,42\%, dikonversikan dalam aktivitas belajar siswa tergolong sangat aktif dan penguasaan materi secara klasikal 90,24\% berdasarkan rentang ketuntasan (85\%-100\%) terkategori sangat baik. Kesimpulan penelitian ini adalah penerapan model pembelajaran generatif dapat meningkatkan aktivitas dan hasil belajar servis dalam permainan bolavoli.
\end{abstract}

Kata-kata kunci: generatif, pembelajaran, aktivitas, hasil belajar, bolavoli

\begin{abstract}
This study aims to determine how the activities and learning outcomes of student volleyball through the application of generative learning models.The research method is quantitative and carried out in 2 cycles, each cycle consisting of planning, implementing, observing and reflecting. The subjects were 42 students of class VIII A2 SMP Negeri 4 Singaraja The results of the first cycle of data analysis namely, student learning activities classically $(\bar{A})$ of $71.68 \%$, converted in the criteria of student learning activities classified as active, mastery of the material in a classical $66.67 \%$ are in the range $(65 \%-74 \%)$ good enough category. The results of the second cycle data analysis namely, the classical learning activities of students $(\bar{A})$ of $91.42 \%$, were converted into student learning activities classified as very active and mastery of the material classically $90.24 \%$ based on the completeness range (85\% -100\%) categorized very well. The conclusion of this study is that the application of generative learning models can improve activity and service learning outcomes in volleyball games.
\end{abstract}

Keywords : generative, learning, activities, learning outcomes, volleyball 


\section{PENDAHULUAN}

Berdasarkan hasil observasi awal yang dilakukan peneliti khususnya pada salah satu pembelajaran pendidikan jasmani yaitu pembelajaran servis dalam pemainan bola voli di SMP Negeri 4 Singaraja, dalam pembelajaran ini ditemukan beberapa masalah yaitu masih terpusatnya pembelajaran pada guru hal itu menyebabkan rendahnya tingkat motivasi siswa untuk belajar, pembelajaran masih bersifat klasikal dan terlihat jelas pada saat observasi proses pembelajaran masih terpusat pada guru, model pembelajaran yang belum tepat sehingga mengakibatkan siswa banyak yang diam dan kurang aktif dan menjadikan pembelajaran kurang optimal ini terbukti dalam hasil observasi awal aktivitas belajar siswa yang rata-ratanya $63,11 \%$. Selain itu juga pada umumnya minat belajar siswa rendah terhadap mata pelajaran pendidikan jasmani, khususnya materi permainan bola voli. Hal ini dibuktikan dengan hasil observasi awal dimana persentase rata-rata siswa yang mengajukan pertanyaan, pendapat dan memberikan saran dalam berdiskusi sesuai dengan materi pembelajaran hanya $13 \%$ serta ketuntasan klasikal kompetensi dasar siswa dalam permainan bola voli khususnya teknik dasar servis adalah rata-rata 54\%. Jika hal ini dibiarkan terus berlangsung maka akan mengakibatkan kompetensi dasar yang harus dimiliki oleh siswa dalam permainan bola voli tidak akan tercapai secara optimal.

Teknik dasar servis merupakan cara melakukan sesuatu keterampilan yang paling dasar dan paling penting dalam permainan bola voli (Ahmadi, 2007:2). Dalam permainan bola voli, teknik servis digunakan untuk memulai suatu jalannya permainan. Tujuan servis yaitu untuk melambungkan bola kelawan, serta melewatkan bola di atas net. Mengingat penguasaan teknik servis dalam permainan bola voli adalah bagian terpenting yang harus dikuasai siswa, maka seorang guru harus dapat menciptakan suasana belajar yang efektif dan efisien. Guru Pendidikan jasmani hendaknya tidak mengajar sekadar sebagaian kegiatan yang menyampaikan pengetahuan, keterampilan dan sikap kepada siswa, melainkan guru hendaknya mengajar untuk membelajarkan siswa dalam kelompok kecil yang bakerja bersamasama untuk mengoptimalkan penguasaan tentang apa yang dipelajari siswa. Mengingat masalah yang dihadapi oleh siswa di atas, jadi bagaimana guru pendidikan jasmani memberikan tanggung jawab belajarnya secara penuh kepada siswa, sehingga siswa dapat belajar mandiri, meningkatkan motivasi dalam melakukan gerakan. Bertolak dari uraian di atas, peneliti mencoba memberikan salah satu alternatif pemecahan masalah yaitu dengan penerapan model pembelajaran generatif. Model pembelajaran generatif ini merupakan pengembangan dari model-model pembelajaran yang telah ada. Model pembelajaran generatif lebih berpusat pada siswa (student centre) dimana siswa lebih aktif, kreatif dan inovatif dalam proses pembelajaran. Siswa diberikan kesempatan lebih banyak mencoba dan memecahkan masalah yang dihadapi dalam proses pembelajaran. Dalam proses pembelajaran ini, guru hanya sebagai mediator dan fasilitator, dimana fungsi guru hanya sebagai pedamping dan mengarahkan proses pembelajaran dan diskusi untuk memecahkan permasalahan yang dihadapi oleh siswa. Permasalahan dipecahkan oleh kelompok masing-masing dan apabila belum ada jalan keluarnya maka akan dibawa ke forum jika dalam forum juga 
belum ditemukan jalan keluarnya barulah guru membantu memecahkan permasalahan tersebut. Jadi model pembelajaran generatif merupakan model pembelajaran yang menitikberatkan pada peran aktif siswa untuk memecahkan permasalahan dalam pembelajaran.

\section{METODE}

Data aktivitas dan hasil belajar siswa diambil dengan menggunakan lembar observasi yang sudah berisikan indikator aktivitas dan hasil belajar siswa. Pengambilan data aktivitas dan hasil belajar siswa dilakukan setiap siklus.

Tabel 1. Lembar Observasi Aktivitas Belajar Siswa

\begin{tabular}{lll}
\hline & $\begin{array}{c}\text { Indikator aktivitas } \\
\text { belajar siswa. }\end{array}$ & $\begin{array}{c}\text { Jumlah Siswa yang } \\
\text { memenuhi indikator (F) }\end{array}$
\end{tabular}

Tabel 2. Asesemen Teknik Dasar Servis dalam Permainan Bola Voli

\begin{tabular}{|c|c|c|c|c|c|c|}
\hline & & & spek yang diama & & & \\
\hline No & Nama & $\begin{array}{c}\text { Sikap } \\
\text { awal }\end{array}$ & $\begin{array}{l}\text { Sikap } \\
\text { perkenaan bola }\end{array}$ & $\begin{array}{l}\text { Sikap } \\
\text { Akhir }\end{array}$ & Skor & Keterangan \\
\hline
\end{tabular}

Sumber: Depdiknas, 2003: 76

Keterangan :

1. Sikap awal $: 3$

2. Perkenaan bola $: 3$

3. Sikap akhir $\quad: 4$

Jumlah $\quad: 10$

Data aktivitas belajar siswa secara klasikal dianalisis berdasarkan prosentase kemunculan tiap item aktivitas belajar kegiatan yang dilakukan siswa selama proses pembelajaran dengan menggunakan rumus

Aktivitas belajar $=\frac{I}{n} x 100 \%$

Keterangan:

$I=$ banyaknya siswa terindikator $n=$ jumlah siswa keseluruhan

Data hasil belajar siswa di analisis dengan rumus
Jumlah skor siswa
$N A=\stackrel{x}{ } \quad 100$
(2)
Jumlah skor maksimal
Analisis Hasil Belajar Siswa secara Klasikal, rumus yang digunakan adalah 
$\bar{X}=\frac{\sum X}{N}$

Keterangan:

$\bar{X}=$ Rata-rata secara klasikal

$\sum \mathrm{X}=$ Jumlah hasil belajar siswa keseluruhan

$N$ = Jumlah siswa

Ketuntasan Belajar (KB) siswa

Jumlah siswa tuntas

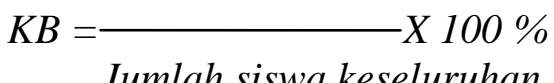

\section{HASIL DAN PEMBAHASAN}

Hasil penelitian siklus 1 adalah Total skor indikator aktivitas belajar siswa sebesar $716,8 \%$ dan rata-ratanya ( $\bar{A}$ ) sebesar 71,68\%. Dikonversikan dalam kriteria aktivitas belajar maka aktivitas belajar siswa secara klasikal tergolong aktif. Sedangkan hasil belajar siswa adalah sangat baik 13 orang atau $(33,33 \%)$, baik 7 orang atau $(17,94 \%)$, cukup 10 orang atau $(25,64 \%)$, kurang 9 orang atau $(23,08 \%)$. Maka siswa yang dikategorikan tuntas adalah sejumlah $76,92 \%$.

Hasil penelitian siklus II adalah Total skor indikator aktivitas belajar siswa sebesar $914,2 \%$ dan rata-ratanya $(\bar{A})$ sebesar $91,42 \%$. Dikonversikan dalam kriteria aktivitas belajar maka aktivitas belajar siswa secara klasikal tergolong sangat aktif. Sedangkan hasil belajar siswa adalah sangat baik 10 orang atau $24,39 \%$, baik 16 orang atau $(39,02 \%)$, cukup 11 orang atau $(26,83 \%)$, kurang 4 orang atau (9,76\%). Maka siswa yang dikategorikan tuntas adalah sejumlah 90,24\%. Dengan indikator capaian baik aktivitas dan hasil belajar secara klasikal sebesar $\geq 75 \%$ maka penelitian dapat dikatakan sudah tuntas dapat dihentikan.
Pembahasan penelitian dimana model pembelajaran generatif merupakan pengembangan dari modelmodel pembelajaran yang telah ada. Model pembelajaran generatif lebih berpusat pada siswa (student centre) dimana siswa lebih aktif, kreatif dan inovatif dalam proses pembelajaran. Siswa diberikan kesempatan lebih banyak mencoba dan memecahkan masalah yang dihadapi dalam proses pembelajaran. Dalam proses pembelajaran, guru hanya sebagai mediator dan fasilitator, dimana fungsi guru hanya sebagai pedamping dan mengarahkan proses pembelajaran dan diskusi untuk memecahkan permasalahan yang dihadapi oleh siswa. Dengan memberikan kepada siswa untuk belajar dan membangun pengetahuanya sendiri sesuai dengan tujuan pembelajaran generatif maka terbukti dengan jelas dengan meningkatnya aktivitas dan hasil belajar siswa. Walaupun demikian ada beberapa kendala yang dihadapi pada saat proses pembelajaran terutama pada siklus I antara lain, Siswa banyak yang terlambat dalam proses pembelajaran karena banyak siswa yang mempunyai tempat tinggal yang tergolong jauh dari sekolah, terdapat beberapa siswa yang tidak hadir dalam proses pembelajaran karena terpilih untuk menjalankan tugas sekolah seperti mengikuti lomba gerak jalan, siswa masih bersifat pasif dan kurang bekerjasama dalam kelompoknya karena metode pembelajaran yang digunakan masih baru dan perlu penyesuaian. Berdasarkan refleksi siklus I tindakan perbaikan yang dilakukan adalah pembelajaran dibawa ke jam sore yaitu pukul 15.30 wita untuk mengurangi jumlah siswa yang tidak hadir dan jumlah siswa yang terlambat dalam proses pembelajaran, mensosialisasikan kembali model pembelajaran generatif 
pada siswa agar siswa lebih paham tentang model pembelajaran yang diterapkan sehingga proses pembelajaran dapat berjalan seperti yang diharapkan, menekankan kembali langkah-langkah gerakan pelaksanaan teknik dasar servis yang benar, memberikan pegertian dan perhatian yang lebih terhadap siswa yang sering tidak hadir dalam proses pembelajaran pada siklus I.

\section{SIMPULAN DAN SARAN}

Kesimpulan dari penelitian adalah penerapan model pembelajaran generatif dapat meningkatkan aktivitas dan hasil belajar servis dalam permainan bola voli.

Sesuai dengan kesimpulan penelitian secara umum penerapan model pembelajaran generatif di atas maka disarankan kepada guru pendidikan jasmani, olahraga dan kesehatan untuk dapat menerapkan model pembelajaran generatif pada proses pembelajaran teknik dasar servis dalam permainan bola voli.

\section{DAFTAR PUSTAKA}

Ahmadi, A. dan J.T. Prasetya.2005. Strategi Belajar Mangajar ( SBM ).Bandung: Pustaka Setia

Ahmadi, Nuril. 2007. Panduan Olahraga Bola Voli. Solo: ERA Pustaka Utama

Aip Syarifuddin \& Muhadi. 2002. Pendidikan Jasmani dan Kesehatan. Jakarta: Depdikbud.

Arifin mulyati, dkk. 2003. Strategi belajar mengajar kimia. Jurusan pendidikan kimia F MIPA Universitas pendidikan Indonesia.

Arikunto. Suharsimi. 2002. Menejemen penelitian. Jakarta: Rineka Cipta..
Bachtiar,dkk. 2001. Permainan Besar II Bola Voli dan Bola Tangan. Jakarta : Universitas Terbuka

Barbara, dkk. 2000. Bola Voli Tingkat Pemula. Jakarta: Rajagrafindo Persada

Hamalik, Oemar. 2004. Proses Belajar Mengajar. Jakarta: Bumi Aksara

Kanca, I Nyoman. 2008. Penelitian Tindakan Kelas. Singaraja: Universitas Pendidikan Ganesha.

Komisaris Kepelatihan PP- PBVSI. 2017. Peraturan resmi permainan bolavoli. Jakarta.

Margono. 2003. Metodelogi Penelitian Pendidikan.Jakarta: Rineka Cipta

Muhajir. 2004. Pendidikan Jasmani Teori dan Praktek. Bandung: Erlangga

Nurhadi, dkk.2004. Pembelajaran konstektual dan penerapannya dalam KBK. Malang: Universitas Negeri Malang.

Sardirman. 2004. Interaksi Motifasi Belajar Dan Mengajar. Jakarta: PT Raja Grafindo Persada.

Sugiarta. 2000. Inovasi Model Pembelajaran Generatif dengan Metode PQ4R Berbantuan Modul dalam Perkuliahan Statistika Dasar. Laporan Penelitian Singaraja: IKIP Negeri Singaraja.

Wahjoedi. 2001. Landasan Evaluasi Pendidikan Jasmani. Jakarta: Rajagrafindo Persada

Wahono Widodo. 2002. Pengajaran dan pembelajaran konstektual (CTL). Jakarta: Depdiknas, Direktorat Jedral Pendidikan Dasar dan Menengah, Direktorat Pendidikan Lanjutan Pertama.

Zainuddin, M dan Masyhuri (2011) Metodologi Penelitian: Pendekatan Praktis dan Aplikatif (Edisi Revisi). Refika Aditama, Bandung. 